\title{
Brexit: Volgende uitdagings vir 'n nuwe era'
}

Toe die Statuut van Rome in 1957 onderteken is om die grondslag te lê vir wat later as die Europese Unie (EU) sou ontwikkel, het die Verenigde Koninkryk (VK) daarna gehunker om gemeenplaas met ander lande in Europa te vind. Die proses het 16 jaar geduur voordat die VK in 1973 lid van die EU geword het en vir 47 jaar was al die VK se diplomatieke en ekonomiese strategieë in die Europese projek vasgevang voordat die VK dit aan die einde van Januarie 2020 onherroeplik vaarwel toegeroep het. Drie groot uitdagings lê vir eerste minister Boris Johnson (hierna afwisselend slegs Johnson) voor.

- Eerstens, om gedurende die oorgangsperiode wat op 31 Desember 2020 eindig 'n permanente ooreengekome verhouding met die EU te beding.

- Tweedens, om na byna vyf dekades van selfidentifisering as 'n de facto Europese staat te verander in 'n soewereine staat, wat 'n eie onafhanklike identiteit en doelwit nastreef. Met die VK uiteindelik op pad om vry van al die omvangryke wette, reëls en regulasies van die EU te word, kan die vrye handel op 'n globale skaal omhels en nagejaag word. Eerste minister Boris Johnson beskou dit as 'n geleentheid om sy land na wêreldwye voortreflikheid te lei; maar, beskou volgens globale terme, strook hierdie euforiese benadering nie heeltemal met die koue werklikhede nie. Trouens, die VK mag na finale ontkoppeling vind dat sy selfstandige plek en invloed in die wêreld verklein het.

- Derdens, moet die eerste minister aan knellende binnelandse vraagstukke aandag skenk. Tuis word gereken dat hy en sy bondgenote onvermydelik die grondslag vir die verbrokkeling van die VK gelê het, want Noord-Ierland en Skotland is nog steeds hoogs ontevrede met die verloop en uiteinde van Brexit.

Onder leiding van die huidige eerste minister, Johnson, is van die onbuigbare voorstelle weggestap wat tot sy voorganger, Theresa May, se ondergang gelei het; of Johnson ten volle besef en aanvaar wat al die implikasies gaan wees om die EU te verlaat, sal net die tyd leer. Sy benadering ten opsigte van die EU berus op drie basiese voorveronderstellings, naamlik visvangregte; 'n gelyke speelveld met regverdige kompetisie; en geen onsekerheid oor die rol van die Europese Geregshof(EG) nie. Word hierdie sleutelonderwerpe bevredigend afgehandel, is 'n nuwe ooreenkoms met die EU teen die einde van 2020 moontlik. Hy is vasbeslote om nie sy land se vissermanne uit te verkoop deur aan die eise van die EU toe te gee dat bepaalde viskwotas in die VK se viswaters afgestaan moet word nie. Regverdige kompetisie hang af van hoe hy soewereiniteit definieer en aan watter voorskrifte van die EU hy wil of sal kan voldoen. Die rol van die Europese Geregshof bly steeds die Gordiaanse knoop wat deurgehak moet word en is 'n uiters problematiese kwessie vir beide kante.

1 Bekendheid word in hierdie opvolgaantekeninge veronderstel met Eksteen se volledige uiteensetting van die Brexit-kwessie, sowel as Leopold Scholtz se repliek daarop, wat albei in die Junie 2019-nommer van die Tydskrif vir Geesteswetenskappe geplaas is: Eksteen, Riaan. 2019. Brexit se politieke en ekonomiese nagevolge en historiese realiteite. Tydskrif vir Geesteswetenskappe, 59(2):266-291; Scholtz, Leopold. 2019. Die ramp van Brexit. Tydskrif vir Geesteswetenskappe 59(2):292-300. 
Aan die begin van Februarie 2020 was Johnson se standpunt dat die VK 'n ooreenkoms met die EU beoog wat byna alle tariewe sal elimineer, maar dat die VK nie aan reëls van die EU gehoor sal gee nie en beslis nie tot 'n oorsigrol vir die EG sal instem nie. Daarenteen bly die EU se reeds bekende standpunt oor die EG nog steeds dieselfde. Indien die VK dus die voordele van 'n enkelmark wil beding, moet die EU se reëls, soos in EU-wette vervat en waaroor die EG 'n toesigrol bly behou, aanvaar word. Hierdie aspek is nooit duidelik in die hersiene Politieke Deklarasie uitgespel wat die EU en die VK uiteindelik laat in 2019 onderteken het nie en ingevolge waarvan die VK uit die EU kon onttrek. In werklikheid is daardie Deklarasie vol onsekerhede gelaat.

Eerste minister Johnson hou met die aanvang van die oorgangstydperk onverbiddelik vol dat hy enige rol vir die EG verwerp. Sy standpunt herinner sterk aan Theresa May se aanvanklike rooilyn oor die EG wat sy later moes afwater. Wat duidelik gestel moet word, is dat die EG nie enige toekomstige verhouding sal reël of beheer nie, maar eerder dat die Hof dispute oor hoe Europese wetgewing geïnterpreteer moet word, sal bly besleg. Op 'n paar uitsonderings na sal alle EU-wette steeds gedurende die oorgangsperiode op die VK van toepassing wees. Die EU vereis dus nie volle oorsig vir die EG nie. Afgesien van handelsaspekte verwag die EU dat die EG sal voortgaan om sy rol ten volle te vervul met betrekking tot veiligheidsaangeleenthede, soos uitlewering en die uitruil van data. Ook hieroor bly die VK omgekrap want hierdeur kan die EU deur middel van sy Hof die outonomie van die VK se regstelsel aantas. Die EG het op 31 Januarie 2020 self sy eie standpunt oor die Hof se rol in die oorgangsperiode soos volg in 'n persvrystelling (nr. 10/20) uiteengesit:

In accordance with the terms of the withdrawal agreement, the Court of Justice is to continue to have jurisdiction in any proceedings brought by or against the UK before the end of the transition period, which is set as 31 December 2020. It is also to continue to have jurisdiction to give preliminary rulings on requests from courts and tribunals of the UK made before the end of the transition period.

Die grootste skuif in 47 jaar in die VK se buitelandse beleid het op 31 Januarie 2020 plaasgevind. As lid van die EU het die VK gehelp om die Unie se buitelandse beleid te vorm. Hoe die VK dit gaan regkry om 'n invloedryke gesag met betrekking tot buitelandse beleid in Europa te bly en dit buite die sfeer van die EU te vermag, gaan veeleisend wees, indien nie haas onmoontlik nie. Die VK is nou 'n buitestander wat met Frankryk en Duitsland op die gebied van buitelandse beleid sal moet meeding. Die onbekende era wat met uittrede uit die EU ingelui is, beteken ook dat die VK nuwe verhoudinge met die VSA, China en Indië, hoofsaaklik op handelsgebied, sal kan smee.

In Februarie 2020 is die VK meer geïnteresseerd om 'n losser ooreenkoms met die EU te probeer bewerkstellig, terwyl dit terselfdertyd ooreenkomste met ander lande wil aangaan wat ongeveer $13 \%$ van die wêreld se Bruto Nasionale Produk verteenwoordig. Dit sal egter moeilik wees om 'n allesomvattende handelsooreenkoms met die VSA te sluit alvorens die terme van die verhouding tussen die VK en die EU nie eers bepaal en afgehandel is nie. 'n Spesiale verhouding wat die VK en die VSA oor baie dekades gehandhaaf het, impliseer in hierdie nuwe tydsgewrig post-Brexit nie noodwendig spesiale ooreenkomste en vergunnings nie. Eerste minister Boris Johnson sal derhalwe 'n groot fout begaan indien hy die VSA se samewerking en instemming as vanselfsprekend aanvaar. President Trump het onlangs nie geaarsel om die eerste minister trompop mee te deel dat sy toelating van China se 5G datastelsel nie die VSA se goedkeuring wegdra nie. 
In sy hoedanigheid as eerste minister lê 'n reusetaak vir Johnson voor om gedurende die oorgangstydperk 'n nuwe bedeling met die EU te finaliseer. Die proses om van die EU ontslae te raak, is ver van oor. Die VK kan nouliks bekostig om teen die einde van hierdie jaar 'n afgrond van die ekonomies onbekende in die gesig te staar, en of dit polities moontlik gaan wees, hang weereens van die politieke wil af wat by albei partye teenwoordig gaan wees. Die uitdaging is vir beide die VK en die EU om binne neergelegde tydsraamwerke hul eens geheel vervlegte ekonomieë finaal te skei en terselfdertyd elkeen se substantiewe belange te beskerm en te bevorder.

Die eerste ontmoeting tussen die twee partye in Februarie 2020 het beslis laat blyk dat die verskille tussen die VK en die EU steeds netso groot is as voorheen. Die oorgangsperiode mag wel na 31 Desember 2020 verleng word, maar dan alleenlik indien daar voor 1 Julie 2020 daaroor besluit word. Na laasgenoemde datum is daar geen omdraaikans nie. Dan moet alle reëlings met betrekking tot die toekomstige verhouding tussen die VK en die EU voor 31 Desember 2020 afgehandel wees. Tans is Johnson vasbeslote om nie so 'n uitstel te versoek nie. Indien die verlangde ooreenkoms nie op 31 Desember 2020 bereik is nie, eindig alle bestaande reëlings tussen die twee partye. Dit kan ongekende chaos en ontwrigting veroorsaak indien 'n geen ooreenkoms-Brexit op 1 Januarie 2021 in werking tree. Wanneer in gedagte gehou word dat die eerste fase van Brexit meer as drie jaar geneem het om afgehandel te word, is die oorblywende maande in 2020 bitter min om 'n substantiewe ooreenkoms te bereik wat die toekomstige verhouding in al sy omvattendheid moet vervat. Baie slaggate sal dus tydens die oorgangstydperk vermy moet word. Wat die tydsverloop in 2020 nog verder kompliseer, is dat vir 'n ooreenkoms om teen einde Desember 2020 bekragtig te word, dit reeds teen Oktober 2020 gefinaliseer moet wees. Indien dit nie gebeur nie, sal die bestaande Onttrekkingsooreenkoms heronderhandel moet word, wat op sy beurt weer deur die Parlement aanvaar moet word, soos wat die geval met die huidige een in 2019 was toe allerlei struikelblokke dit byna verongeluk het. Die periode tussen Oktober en einde Desember 2020 is noodsaaklik, aangesien dit moontlik is dat nasionale parlemente - selfs streeksparlemente - in die EU die finale ooreenkoms moet goedkeur, iets wat allermins blote formaliteite is. Een voorbeeld is toe die streek Wallonië in Oktober 2016 vir weke verhoed het dat België tot die EU se handelsooreenkoms met Kanada kon toestem.

In die VK sal eerste minister Johnson poog om verandering ten opsigte van verskeie interne aangeleenthede teweeg te bring, soos byvoorbeeld die basiese beginsels oor staatsbetrokkenheid in die ekonomie en infrastruktuur- en streeksontwikkeling. Hierin sien hy die geleentheid om die ekonomie van die VK te "herlaai", maar ekonome meen egter dat die uittrede sy taak sal bemoeilik en dat die ekonomie tot soveel as 5\% oor 'n tydperk van 15 jaar mag daal. Gedurende die oorgangstydperk sal die VK nie net die EU se reëls en wette moet eerbiedig nie; dit sal ook nog aanhou om fondse tot laasgenoemde by te dra. Baie dinge sal egter dieselfde bly, uitgesonderd die volgende vername uitsonderings:

- Geen verdere verteenwoordiging vir die VK in die Europese Parlement nie.

- Geen regters van die VK op die regbank van die EG nie.

- Geen deelname van die VK aan spitsberade van die EU nie.

- Nuwe paspoorte vir burgers van die VK.

- Geen uitlewering van Duitse burgers aan die VK nie. Die Duitse grondwet maak nie voorsiening daarvoor dat sy burgers aan nie-lidstate van die EU uitgelewer word nie. Nie-Duitse burgers sal wel nog uitgelewer word. 
Wat die geostrategiese aspekte van Brexit betref, moet beklemtoon word dat die EU nie meer net 'n gemeenskapsmark is nie. Dit het tot 'n politieke en geïnstitusionaliseerde instelling van die hoogste orde ontwikkel, danksy die EG wat Europese integrasie tot hoë hoogtes bevorder en verseker het. Dit is juis om hierdie rede dat Brexit ook baie uitdagings vir die EU skep. Bondskanselier Merkel reken dat Duitsland 'n gedaanteverwisseling mag ondergaan. Terwyl 'n donker prentjie met politieke onrus vir die VK met sy onttrekking voorspel is, was dit 'n land soos Frankryk wat deur massiewe betogings teen 'n steeds groeiende onpopulêre regering geruk is. Met die VK se uittrede is die EU nie net 15\% van sy ekonomie kwyt nie, maar ook sy grootste militêre spandeerder en Londen as die wêreld se internasionale finansiële hoofstad. Dan laat die VK se vertrek die EU met 'n enorme begrotingstekort van Euro 75 miljard vir die hele periode tot 2028. Groot onenigheid en spanning lê voor oor hoe hierdie bedrag deur die oorblywende 27 lidstate geabsorbeer moet word.

Noudat die VK uiteindelik uit die EU is, moet die Unie ook besluit wat dit eintlik wil wees. Vir jare het bitter verskille oor immigrasie, asiel, verdediging en veiligheid die verhoudings tussen die VK en die EU versuur. Wat die EU nou tot introspeksie sal lei, is die feit dat al hierdie onderwerpe die bron van hewige dispute ook binne die EU is, afgesien van die VK se status. Die rol wat Duitsland en Frankryk in die afgelope drie jaar gespeel het, het geensins gehelp om hierdie onderwerpe tot oplossings te dryf nie juis omdat hulle twee self aanhoudend meningsverskille daaroor gehad het. Leierskap in die EU is gebrekkig om die Unie se eie interne probleme op te los. Die nuus dat die uitverkore persoon wat Merkel as bondskanselier sou opvolg nie meer beskikbaar is nie, laat leierskap in Duitsland in 'n warboel. Wat in Duitsland gebeur, is nie net vir die land belangrik nie, maar vir die hele EU. Politieke en ekonomiese probleme sal kombineer om Duitse groei te beperk en dit sal uiterste vermoë verg om steeds 'n vername en leidende rol in die EU te speel. Dit juis op 'n tydstip waar daar soveel van Duitsland afhang om die EU verenig te hou, die groeiende globale rol van China bewustelik te hanteer, die transatlantiese verhouding te versterk (President Trump dreig steeds om 25\% tarief op Europese motors te hef), en westerse waardes in stand te hou. Die EU staar gevolglik 'n periode van geostrategiese verskuiwings in die gesig, wat verder bemoeilik word met uiteenlopende standpunte oor Rusland, vergroting van die EU, die swak toestand van verhoudinge met die VSA, aanslag op multilaterale instellings en veiligheid. Dan veroorsaak lidstate soos Hongarye en Poland ook besondere hoofbrekens met hul najaag van nasionale agendas.

Sodanige probleme word slegs verbloem deur die verenigde front wat voorgehou word wanneer die VK se nuwe status ter sprake kom. Wanneer Brexit later nie meer die EU verenig nie en groter skeurings in die mondering ontstaan, sal die prekêre magsbalans tussen Duitsland en Frankryk beslis verder ontbloot word. In daardie proses sal Frankryk heel waarskynlik die swakste daaraan toe wees en dit te wyte aan Brexit. Dit is dus nie verbasend dat die Franse president so knaend veg om die VK sover te kry om sy wette te wysig om die reëls van die EU te weerspieël nie; en voorts dat hierdie beginsel in die nuwe handelsooreenkoms vervat moet word nie.

Brexit is reeds nadelig vir beide die VK en die EU en sal aanhou om skadelike gevolge op die lang termyn vir albei te hê. Dieselfde geld vir die VK se plek in die wêreld en die welsyn van sy vier Unies. Dit is duidelik 'n verlies vir die EU, sowel polities as ekonomies, dat een van sy grootste lidstate met 'n aansienlike ekonomie onttrek het. Op die kort termyn mag die gevolge daarvan dalk groter vir die VK wees. Ten spyte van die VK wat soms 'n moeilike lid was, was dit egter in die geheel gesien 'n bron van idees, balans en globale projeksie in en vir die EU. Tydens onderhandelinge in verband met die onttrekkingsooreenkoms het die EU eenheid en gemeenskaplike doelwitte nagestreef. Alhoewel pro-EU sentiment in baie lidstate 
daardeur versterk is, is die uitdagings wat tot Brexit gelei het nog steeds aanwesig, soos defektiewe immigrasie, gebrek aan mededinging en ondoeltreffende besluitneming - kwessies waaraan die EU aandag sal moet skenk om hierdie tekortkominge so gou doenlik reg te stel. Daar moet in gedagte gehou word dat die meeste van hierdie interne probleme van die EU die Euro, immigrasie, demokrasie en veiligheid - nie deur die VK veroorsaak is nie. Inteendeel.

Indien ingesien word dat Brexit ' $n$ waarskuwing en wekroep tot hervorming is, sal dit tot voordeel van die EU wees. Op die gebied van verdediging en veiligheid sal die EU se onderlinge samewerking en vermoëns verskerp moet word om die VK betrokke te bly hou met verwikkelinge op hierdie gebiede. Indien nie, sal Brexit nie lei tot potensiële hervorming binne die EU nie. Dan sal dit eerder kon bydra tot Europa se strategiese irrelevansie op die lange duur. Nadat daar vir so lank op Londen gesteun is, is dit die EU se taak om nie geleenthede te verspeel nie.

Die VK was een van 'n paar lidlande in die EU wat werklik 'n globale buitelandse beleid nagestreef het en wat 'n groot rol gespeel het om gestalte aan die EU se antwoord op internasionale krisisse te verleen. Die verlies aan ervare diplomatieke en militêre personeel laat die EU swakker daaraan toe in terme van nasionale veiligheid en buitelandse beleid. Ook was die VK instrumenteel daarin om die EU se wetstoepassing en binnelandse samewerking ten opsigte van veiligheid te versterk te midde van toenemende bedreigings. Trouens: eintlik het die VK' $n$ belangrike rol vervul om die EU te skep soos wat dit tans bestaan, en die EU sal dit bepaald mis.

\section{RiaAn Eksteen}

Senior Navorsingsgenoot

Fakulteit Geesteswetenskappe

Universiteit van Johannesburg

E-pos: reksteen@swakop.com 